\title{
Analysis of Russian Rhetorical Devices
}

\author{
Dehua Liu \\ School of Information Management, Tropical Agriculture and Forestry College, Hainan University, \\ Danzhou, Hainan, 571737
}

Keywords: Russian rhetoric; Russian level; Russian

\begin{abstract}
According to the handbook of linguistic and linguistic tools of communication published in Germany, 5651 languages have been identified. There is no doubt that every language has its own unique rhetorical device. Russian, one of the six official languages of the United Nations, certainly has its own rhetorical devices.
\end{abstract}

\section{Introduction}

Russian rhetoric means is a kind of language means, which can obtain certain functional rhetoric effects, or express our inner subjective feelings, or conduct subjective evaluation with certain emotional color. Russian rhetorical devices include not only those with rhetorical colors, but also those language units that can acquire a certain color in the context or context.

\section{Phonetic rhetoric devices}

The language level can be divided into three pronunciation styles: formal, neutral and colloquial. for instance: The formal style is less pronounced, A very large number of foreign words in Russian that stress the first syllable [o] are generally not weakened and are still pronounced as [o]. There are far more colloquial words than formal ones. The spoken language style, on the whole, is opposite to the written language style. This is determined by its special status in the Russian functional form. The spoken language style is the most traditional communicative language style, which serves the daily communication field. It stipulates the familiar relations and social commonalities between the interlocutors, informal communication. The colloquial style is characterized by popularization. People of different ages and professions use the spoken language in their daily life, as well as in informal or private communication in the fields of social politics, production and labor, teaching and research. It is also widely used in literature. Spoken language takes a special place in modern Russian. This is the characteristic of national language all the time. As in all other languages, it is a phenomenon of a later period, often a short historical period. The decisive feature of oral style is that it is used in the unprepared, informal communication in which the speaker directly participates. In Russian learning, intonation is an important means to give expression and evaluation of emotion. Therefore, phonetic methods play an important role in functional rhetoric and emotional expression. It is because of this that three new disciplines of linguistics have been created: phonetics, rhetoric of voice, phonetic semantics.

\section{Rhetorical devices at the word formation level}

The evaluation color expressed by affixes of different parts of speech is different. The most expressive is the suffix of subjective evaluation of nouns. A word variant is formed by affixes, these different variants obtain specific functional rhetorical colors, for example, the spoken language、 written language、 proverb. They express a variety of emotions: miss、 once、admire v boredom and the like. 


\section{Rhetorical devices at the lexical level}

Neutral words are clearly distinguished from the standard Russian dictionary. Neutral words are universal, It is used in all languages to form the basic vocabulary of Russian. The vocabulary of written language is mainly used in the writing style, that is, the scientific style, the official style and the political style. There are also spoken words. Oral vocabulary mainly appears in oral or literary style.

\section{Rhetorical devices at the grammatical level}

Rhetorical devices at the grammatical level can be divided into two categories according to their rhetorical functions, that is, pure language means and speech function. Pure language (morphology) means constitutes the polymer of lexical rhetoric. The polymer of lexical rhetoric, it means disparate variants of morphology, for instance, вода_-воду (water)、 за море_—за моря ( Go abroad)、 and synonymy of morphology, for example, уйди-ушёл бы (Please go away)、 яйцо—— - ийца (egg). The linguistic rhetoric of these variants is different, but the meaning is not different.

Speech function means or grammatical language units are different in rhetoric color from pure language means. It depends largely on the functional semantic category of lexical language units__abstract/summary/concretization. For example, the scientific style is a logical concept language, it is characterized by maximizing abstraction and generality. Close to scientific style is the style of official document affairs. The opposite of these two styles is the daily colloquial style. The style in between is literary style.

As for the political discourse style, one part of the style is close to the literary language, the other part is close to the scientific or official affairs style.

Grammatical rhetorical devices include nouns, adjectives, verbs and other forms. For example, the same present tense form of the verb has different meanings in different functional languages. In the form of scientific language, the verb present tense denotes the superpresent tense (the present tense transcends time), however, in political discourse the verb present tense denotes the present or the present tense of an interview.

\section{Rhetorical devices at the syntactic level}

Russian syntax provides a rich variety of variants for expressing the same idea. These variants have different rhetorical colors, at the same time they solidify in different styles. For example, the idea that students should study well. Here are at least eight completely different expressions:

Students should study well.

The student's task is to study well.

A student should be like a student.

Students ought to study well.

Since you are a student, go to study!

What does a student do if he doesn't study well?

Students do not study well, who study?

All these sentence variants, completely different expressions express various subjective modalities of meaning. The degree of expression of subjective modality meaning decreases gradually from the last sentence to the first sentence, so different sentences are used in different situations. 


\section{Figures of speech and semantic word}

The rhetorical method, that is, the Russian descriptive means of expression is usually divided into two categories: semantic and syntactic. The most commonly used semantic terms include metaphor、 simile、metonymy、 modifier、 personification, exaggeration, and antinomy (also called oxymoron)、 equivoque、sarcasm、 circularity, etc. These rhetorical methods only endow the speech with the iconicity, making the speech more vivid and more effective to arouse the audience's resonance. They have no relation to do with the structure of speech. Now, I want to briefly introduce two kinds of semantic figure: simile and personification. Personification is the giving of human features and characteristics to inanimate objects. A simile is a similar characteristic between two things, in Russian simile is mainly expressed in the following ways:

(1) The fifth case of a noun. For example, Снежная пыль столбом стоит в воздухе. (Snow, such as building.)

(2) The comparative degree of adjectives and adverbs. For example, Ты всех милее , всех дороже , русская земля. (You are so lovely, so precious, the land of Russia.)

(3) A phrase with a comparative conjunction. For example, Внизу, как зеркало стальное , синеют озера струи. (The lake water flowed under my feet was like a bright mirror.) Белей, чем горы снеговые, идут на запад облака. (Even whiter than the snow mountains, clouds flow west.)

(4) Vocabulary means. (Usually we use these words: like、similar、as if and so on.) For example, Eë любовь к сыну была подобна безумно. (Her love for her son approximated madness.)

But syntax is different. Syntactic devices not only have the function of description and expression, but also have syntactic features. The most common syntactic devices include simile, progressive, ellipsis, duality, parallel, segmentation, staggered arrangement, rhetorical question, rhetorical apostrophe, etc.

\section{Conclusion}

Russian rhetorical devices are used in various articles or practical articles to improve the expression effect, the set of methods expressed in language writing. A way of improving the function of language expression by rendering, adjusting statements, and using specific expressions. Master the Russian rhetoric, which can let us in the oral expression and the written language application is better, like a fish in water.

\section{Acknowledgements}

Fund Project: Student Science and Technology Innovation Support Project of Tropical Agriculture and Forestry College of Hainan University

\section{References}

[1]. Zhang Xiangrui, a language variant of Russian advertising [J], Foreign Language Research, 2006, (2).

[2]. Zhang Xiangrui, Pragmatic Strategy of Russian Advertising Language [J], Continuing Education Research, 2004, (3)

[3]. Zhang Xiangrui, on the information appeal of advertising texts [J], Journal of Yanshan University, 2006, (2) 